Veljko Turanjanin, LL.D. ${ }^{1}$

Assistant Professor,

Faculty of Law, University in Kragujevac,

Emir Ćorović, LL.D.

Assistant Professor,

State University of Novi Pazar

Dragana Čvorović, Ph.D.

Assistant Professor,

Academy of Criminalistic and Police Studies at Belgrade
ПРЕГЛЕДНИ НАУЧНИ ЧЛАНАК doi:10.5937/zrpfni1777075T

UDK: 343.55(497.11)

Рад примљен: 15.10.2017.

Рад прихваћен: 05.12.2017.

\title{
DOMESTIC VIOLENCE IN SERBIA
}

\begin{abstract}
Domestic violence is one of the most complex criminal issues, representing negation of the basic human rights and freedoms protected by a number of international documents and national legal regulations, starting with the right to life to the right to safety. The authors analyze this increasingly common form of violence (psychical, psychological, economic and sexual) as a social phenomenon that has its substantive criminal law aspect and criminal procedure aspect, neither of which eliminates the causes of its origin but only treats the consequences. Family violence primarily affects women. The authors have conducted a survey for the period of ten years of the Criminal Code application in order to examine the criminal offense of the domestic violence, procedure and perpetrators.
\end{abstract}

Keywords: domestic violence, cause of violence, civil law protection, criminal law protection, domestic violence jurisprudence.

\section{Introduction}

Domestic violence is a global health and criminal justice problem with enormous consequences for the health of millions of women and children around the world, which has attracted public interest only during the last 20 years. However, the phenomenon is much older and has existed for centuries. Essentially based on causing harm to others, violent conduct prevented men from leaving their wives

1 vturanjanin@jura.kg.ac.rs

ecorovic@np.ac.rs

dragana.cvorovic@kpa.edu.rs 
and so destroying the family unit. Although known for centuries, it has remained unchanged but the phenomenological expressions of this phenomenon have multiplied (Kovačević \& Kecman, 2007: 152). Unfortunately, such treatment of women was considered completely normal and natural (Brewster, 2002: 23). Although most attention is given to women when talking about domestic violence, we should not ignore domestic violence against children. Children are the silent victims of domestic violence, but they may also be victims or witnesses of violence. Lots of children of school and pre-school age live in families where violence occurs, which significantly damages their growth, making them anxious, depressed and miserable (Sterne \& Poole, 2010: 11). Any form of violence against children threatens their basic need for security, trust and love, leaving lasting consequences for their mental and physical health (Hanak, Tenjović, IšpanovićRadojković, Vlajković \& Beara, 2013: 76). The extent to which children's problem with domestic violence is considered serious is best illustrated by publishing the advice of children who have suffered abuse to other children on how to deal with the domestic violence (Mullender, Hague, Imam, Kelly, Malos \& Regan, 2002: 233-240). Astounding is the fact that, for example, in the UK, according to the study conducted in 2006, one million children are exposed to domestic violence (Bentovim, 2009: 25), while over a million violent crimes in 1998 were committed by former or current partners in the community, where in the $85 \%$ of the cases the victim was a woman (Brewster, 2002: 25). In the UK, in 1991, 41\% of killed women were killed as victims of domestic violence (Locton \& Ward, 1997: 7). However, it should be mentioned that the discussion on domestic violence is almost always directed toward a man who abuses his wife and children. But both women and men can be found in both roles (Hamel, 2007: 4). In other words, even the reversed process can be very widespread. However, due to the fact that men almost never report such violence, systematically conducted researches on this problem are rare (Mullender, 2006: 11; see Douglas \& Hines, 2011). At the same time, violence may be sustained by the elderly people; thus, according to some sources, between $4 \%$ and $6 \%$ of the population of people older than 65 sustain some form of domestic violence (Jovanović, 2012: 249). Certainly, it is not a new phenomenon but this social problem has only recently been recognized as an important aspect of family violence (Anetzberger, 2008: 12).

The most common form of domestic violence is violence against women. Unfortunately, women are at a greater risk in their own homes rather than in the street (Roberts, 2007: 4). The escalation of this type of violence has prompted lawmakers to address the issue and react in different fields of law, both at the national and international level, because despite the fact that the victim suffered violence one or more times, their injuries and/or trauma may be permanent in nature and this has to stop (Roberts, 2002: 5). Although it is a problem that exists in all 
countries of the modern world (see Parker \& Parker, 2003), it should be borne in mind that legal norms are only the tip of the iceberg in the fight against domestic violence, which entails efforts of many psychologists, sociologists, doctors and lawyers, social workers and police officers (Vlašković, 2008: 3). In situations of domestic violence, when one member of the family approaches another from the position of force and power, the victim can be protected only by a bigger and more powerful force that will curb thugs, and that force is the state (Vlašković, 2013: 184). Domestic violence occurs in every social, cultural and ethnic group, and it is not tied to specific socio-demographic factors (Mildorf, 2007: 30). Although it is most visible in the poor strata of the population, it is recognized as a problem that permeates the middle and high class (Roberts, 2007: 6).

\section{The Normative Framework of Regulating Domestic Violence}

In the Republic of Serbia, a special normative framework for combating domestic violence was created in 2002, when the crime of domestic violence was defined in the Article 118a of the Criminal Act of Serbia. ${ }^{2}$ Before that, Yugoslavia, as the legal predecessor of Serbia, had ratified the UN Convention on the Rights of the Child, ${ }^{3}$ which does not constitute a legal basis for the stated incrimination but requires States Parties to take various measures to protect children from different forms of violence, abuse and the like. Otherwise, the first Proposal of the model for the protection against domestic violence was made in Serbia (Yugoslavia) in 1998, which is provided in addition to the criminal and civil law protection from domestic violence. Of course, even before the incrimination of domestic violence as a special criminal offense, some forms of this phenomenon were subject to criminal liability and punishable either as criminal offenses of bodily harm, insult, slander, endangering safety, violent behavior, or under the norms of misdemeanor law, primarily through infringements against public order and peace. However, the envisaged offences did not protect victims of domestic violence as such.

The Family Act (hereinafter: FA) of the Republic of Serbia, which was adopted and entered into force in $2005,{ }^{4}$ introduces the civil (family law) protection

2 Criminal Act of Serbia, Official Gazette of Serbia no. 26/77, 28/77, 43/77, 20/79, 24/84, 39/86, 51/87, 6/89, 42/89, 21/90, 16/91, 26/91, 75/91, 9/92, 49/92, 51/92, 23/93, 67/93, 47/94, 17/95, 44/98, 10/02, 11/02, 80/02, 39/03.

3 Act on the ratification of the UN Convention on the Rights of the Child, Official Gazette SFRY, no. 15/90, 4/96 and 2/97.

4 The Family Act of Serbia (hereinafter: FA), Official Gazette of Serbia no. 18/2005, 72/2011 and $6 / 2015$. 
against domestic violence. The Serbian Criminal Code (hereinafter: $\mathrm{CC})^{5}$, which was adopted in 2005 and entered into force on $1^{\text {st }}$ January 2006, criminalizes domestic violence in Article 194 CC. Serbia also adopted the Act on the Prevention of Domestic Violence (hereinafter: PDV Act), ${ }^{6}$ which entered into force on 1st July 2017. What remains is the protection in the field of misdemeanor law, which is not explicit as the latter two but it is achieved indirectly through provisions contained in the Act on Public Peace and Order (hereinafter: PPO Act). ${ }^{7}$ In addition, in 2013, Serbia ratified the Council of Europe Convention on preventing and combating violence against women and domestic violence, ${ }^{8}$ which was adopted on $11^{\text {th }}$ May 2011 in Istanbul, and is therefore known as the Istanbul Convention. Bearing in mind that the Istanbul Convention has become an integral part of our internal law, the provision in Article 3 (par. 1, point b) of the ratification Act specifies that "domestic violence means any kind of physical, sexual, psychological, or economic violence that occurs within the family or household, or between former or current spouses or partners, regardless of whether the perpetrator or counterparts shared the same residence with the victim". A similar determination of domestic violence is provided in Article 3 (par. 3) of the Act on the Prevention of Domestic Violence. It should be noted that some former Yugoslav countries (Croatia, Montenegro, and Bosnia and Herzegovina at the entity level) have enacted special laws aimed at combating domestic violence, ${ }^{9}$ mainly relating to misdemeanor protection. These legislative undertakings are certainly expected to be greatly affected by the Istanbul Convention, as has been the case in Croatia since the enactment of the new Penal Code (Turković \& Maršavelski, 2013: 206).

\section{Definition of Domestic Violence and some of its Features: a criminological aspect}

Relying on the classification of violent crime in two categories (traditional and new), forms of domestic violence can be classified in the second category (Ignja-

5 The Criminal Code of the Republic of Serbia (hereinafter: CC), Official Gazette of Serbia no. 85/2005, 88/2005, 107/2005, 72/2009, 111/2009, 121/2012, 104/ 2013 and 108/2014.

6 Act on the Prevention of Domestic Violence (PDV Act), Official Gazette of Serbia no. 94/2016.

7 Act on Public Peace and Order (hereinafter: PPO Act), Official Gazette of Serbia no. 6/2016.

8 Act on the ratification of the CoE Convention on preventing and combating violence against women and domestic violence, Official Gazette of Serbia no. 12/2013.

9 Act on Protection from Domestic Violence, Official Gazette of Croatia no. 137/09, 14/10, 60/10; Act on Protection from Domestic Violence, Official Gazette of Republic of Srpska no. 102/2012, 108/2013, 82/2015; Act on Protection from Domestic Violence, Official Gazette of Bosnia and Herzegovina no. 20/2013; Act on Protection from Domestic Violence, Official Gazette of Montenegro no. 46/2010, 40/2011. 
tović, 2002: 152). There are many definitions, but attention should be paid to two defining elements: what is meant by violence, and what is meant by family. Thus, some authors consider the physical component of violence; others include threats and intimidation, while the third group of people also considers the acts of psychological and emotional aggression. One problem that occurs when determining domestic violence is whether it includes only the violence of men over women, or women over men, as well as violence between same-sex partners (Brewster, 2002: 24), without forgetting that a much wider circle of people can be victims of this type of violence (children, parents, etc.).

Regardless of the particular form of violence, its aim is to take complete control over the person who has been subjected to violence (Summers \& Hoffman, 2002). Then, it means that every act of physical, psychological, sexual or economic abuse occurs or has occurred is considered to be domestic violence, the one that occurs between current or former partners, regardless of the existence and form of their life community, parents and children, as well as other relatives and other persons who have been with each other or are still in emotional or sexual relationship (Cf. Vlašković, 2008: 13). So, from the above definitions, we can isolate four basic forms of domestic violence. These are physical, psychological, sexual and economic violence. These terms can be defined differently in different branches of law but, here, we will try to give their most acceptable definitions. Thus, bringing together criminal justice and the concept of family violence, physical violence is defined as any presumptuous, reckless and malicious behavior which endangers the life or physical integrity of the victim (Vlašković, 2008: 17-18). Sexual violence is any violation of sexual freedom and sexual morality, which covers every aspect of degradation and humiliation on the basis of sex, regardless of whether there is unlawful action (Petrušić \& Konstantinović Vilić, 2005: 30). ${ }^{10}$ Psychological violence is any form of bold, reckless or malicious behavior, which leads to the violation of psychological integrity, mental health and/or the serenity of family members (Vlašković, 2008: 24). Finally, economic violence involves the abuse of their financial resources or restricting the victim's access to joint financial resources in order to maintain control over other family members. Some authors also mention social violence as a form of domestic violence, which is aimed at isolating the victim from the social environment by banning the visitation and contact with other people (Lukić, 2011: 270).

10 Physical and sexual violence are often correlated. According to one study, $33 \%$ of women who suffered sexual violence were beaten (Mullender, 2006: 22). The violence is brutal and degrading (Roberts, 2002a: 49). According to some data, approximately 8.7 millions of women are subjected to violence each year (Roberts, 2002b: 66). However, violence seldom remains in the family; the abuser often harasses the wife's family and friends, especially if she left the family community (McGee, 2000: 41). 


\section{Family Law Protection against Domestic Violence}

\subsection{Substantive Provisions}

In its basic provisions, the Serbian Family Act (FA) lays down the explicit prohibition of domestic violence, providing that everyone has the right to protection from domestic violence in accordance with the law. The term domestic violence is defined in Article 197 (par.1) of the FA which stipulates that domestic violence is the behavior of a family member endangering the physical integrity, mental health or tranquility of another family member. Domestic violence exists if the following conditions have been met cumulatively: 1) a family member performs a violent act or fails to act; 2 ) the violent action was committed intentionally or by gross negligence; 3 ) there must be a causal link between the actions of a family member and the injuries sustained by another family member; 4) this action violates or threatens any personal benefit of another family member, such as: the physical integrity, mental health or serenity" (Babić, 2014: 51-52).

The main problem with the quoted provision is that the result is interpreted as a violation of the envisaged social values, although the provision takes into account the element of endangerment only. Moreover, the notion of endangerment is considered to be general and vague, even though it is the basic concept of criminal justice with a clear meaning and place. It is obvious that there is no distinction between offences (delicts) of injury and offences of endangerment, which does exist in criminal law theory. On the other hand, in the family law practice, the occurrence of the consequence as well as the causal link is rarely determined. The emphasis is placed on behavior, i.e. the act of violence. ${ }^{11}$

11 For example, the judgment of the Court of Appeal in Novi Sad, Gž 2 529/14 of 15.10.2014, reads: "Violence in the family in terms of the provisions of the Family Law presupposes any behavior that deviates from the usual standards of behavior and communication with family members; continuity (permanence and repetition of such behavior) is not necessary for it to be qualified as domestic violence, which does exist in the case at issue; but, in certain situations, one act of behavior is sufficient to be characterized as domestic violence". (See: http://www.ns.ap.sud.rs/index.php/src/sudska-praksa/873-gz2-529-14, access 27.02.2016). Another obvious example can be found in the decision of the Court of Appeal in Belgrade, Gž 2 br. 366/10 of $17^{\text {th }}$ May 2010, which states: "The legal definition of domestic violence is very broad and covers all possible manifestations of violence. It is therefore necessary to ensure a timely reaction of system institutions to domestic violence, to determine measures for protection against domestic violence before it has taken more severe forms and, thus, prevent the escalation of violence. In any proceedings for protection against domestic violence, the court should examine whether and how violence is manifested, determine whether the specific conduct (which includes certain actions, failure to act, gestures, etc.) of the alleged perpetrator has actually occurred and, then, qualify such behavior as domestic violence. Audacity, recklessness and bad faith are the elements and essential characteristics of domestic violence, which clearly distinguish it from the approved behavior. These are the 
In addition to the general definition, Article 197 (par. 2) of FA states that pursuant to paragraph 1, domestic violence specifically includes: 1) causing or attempting to cause bodily injury; 2) causing fear by the threat of death or bodily harm to a family member or a person close to them; 3 ) forced sexual intercourse; 4) incitement to sexual intercourse or sexual intercourse with a person under 14 years of age or a disabled person; 5) the restriction of freedom of movement or communication with third parties; 6 ) insult, and other presumptuous, reckless and malicious behavior (see Panov, 2012: 145). Such a legislative approach has been criticized for the fact that most or all of the listed actions are considered to be criminal offences, but their existence cannot be determined by the civil court in civil proceedings because it is the subject matter of criminal proceedings. It practically means that the fate of the litigation would depend on the outcome of the subsequent proceedings (Škulić, 2014: 44). Therefore, such standards are considered to be unrealistic.

Otherwise, when the general definition of domestic violence from the FA is compared to the criminal offense with the same name stipulated in Article 194 par. 1 of the CC, we can see that the ultimate normatively determined result is identical (although somewhat differently formulated) in both delicts: a threat to the protected goods/values. However, we believe that these two threats do not always have the same intensity in terms of the existence of one or the other delict. Accordingly, there is a possibility that the conditions for providing family law protection prescribed in the FA are fulfilled but that there is no criminal offense from Article 194 of the CC. ${ }^{12}$

standards whose content can be determined only relationally - in relation to general social norms and values. These are typical legal standards, but their contents are yet to be imbued with the court's system of values. It means that, using the objective criteria and taking into account all the specific, objective and subjective circumstances of the case, the court should take the stance that a concrete action or behavior can be regarded as insolent, arrogant and malicious behavior. In doing so, the court has to show 'zero tolerance' to violence, which means that any behavior that deviates from the normal dealing and communication with family members' should be qualified as domestic violence". (See: http://www.bg.ap.sud.rs/lt/ articles/sudska-praksa/pregled-sudske-prakse-apelacionog-suda-u-beogradu/gradjanskoodeljenje/parnica/porodicno-pravo/gz2-366-10.html). It seems that the designated parts of the cited decision prove the direction of the thesis we have advanced.

12 For example, Article 197 (par. 2, point 6) of the FA states that domestic violence also includes "insult, as well as any other presumptuous, reckless and malicious behavior." Proper interpretation of the FA provisions on domestic violence (Article 197 par. 2 FA) starts with the formulation: "Violence in the family, in terms of paragraph 1 of this Article, shall in particular refer to..."). It can be concluded that the above behavior should endanger one of the prescribed goods/values of another family member (considering the nature of the action, this will be mental health or tranquility). However, as we will see later, insolent and ruthless behavior is referred to as methods of committing the criminal act of domestic violence. We believe that such interpretation would be acceptable, i.e. that insolent and ruthless behavior 


\subsection{Measures of Protection against Domestic Violence}

The family member who practices domestic violence may be awarded one or more protection measures against domestic violence, which temporarily prohibit or limit the personal relationships with another family member. The protection measures against domestic violence are: 1) an order for eviction from the family dwelling or house, regardless of the right of ownership or lease of the real estate; 2) an order for the family to move into an apartment or house, regardless of the right of ownership or lease of real estate; 3 ) the prohibition of approaching the family member at a certain distance; 4 ) the prohibition of access to the place of residence or workplace of a family member; 5 ) the prohibition of further harassment of a family member.

If the family apartment or house is owned by the perpetrator, the eviction order and the order to move into an apartment do not interfere with the right of ownership as such, but they limit the right of use (Ignjatović, Pavlović Babić \& Lukić, 2015: 47). Restraining orders concerning approaching a family member and access to premises are said to represent the most significant protection measures because "the decision on the separation or de facto termination of the community produces the risk of an escalation of violence", while these measures should prevent the bully from "getting into contact with victim in any way" (Ignjatović, et al. 2015: 47). The prohibition of further harassment is considered to be the mildest protection measure against domestic violence; it is characterized by the fact that the judgment does not mention certain forms of domestic violence but it prohibits any form of such violence (Ignjatović, at al. 2015: 47). ${ }^{13}$

affects (to some extent) the mental health and tranquility of another family member. Thus, the criteria for imposing some of the protection measures envisaged in the FA are met even without the actual commission of the criminal offense stipulated in Article 194 of the CC, given that such endangerment (by taking the aforementioned actions) is not relevant in the criminal context. Insolent and ruthless behavior can be interpreted more extensively, and it would not be right for any act to lead to criminal reaction, which is also in accordance with the subsidiary character of criminal law protection. Considering the aforementioned concept of "zero tolerance" for family violence, this interpretation has a significant place in family law judicature as well.

13 In the Decision Rev. 2844/10, the Serbian Supreme Court of Cassation gave its opinion on the nature of these measures, stating that: "Statutory protection measures are not just punishment for the perpetrator of domestic violence, but they also have a preventive effect because they admonish and warn the offender of what legal consequences could be expected in case he repeats his criminal act in the future; so, they act with the aim of preventing the repetition of violent behavior. The protection measures must be effective and efficient in order to achieve their goals in the field of prevention, both special and general, and their ultimate objective is the protection of the family as the basic unit and the most important community in the human society, including both family as a whole and each of its members individually. They do not only protect the victims of violence but also the perpetrators 
The awarded protection measure against domestic violence may last up to one year, but it may be additionally prolonged if the reasons for imposing such a measure still exist. However, does it mean that the respective measures can be extended endlessly? In effect, this measure can be terminated before the expiry of the specific period for which it has been awarded if the reasons for imposing such a protection measure no longer exist. The FA stipulates that the time spent in custody, as well as any form of deprivation of freedom related to a criminal offense or a misdemeanor, is calculated in the duration of the awarded protection measures against domestic violence. The ratio of such a provision is questionable. For example, it may happen that the duration of the imposed protection measure against family violence has expired while the convicted offender has been serving a term of imprisonment. Thus, the aim of this provision is not very clear because the very act of deprivation of liberty (imprisonment) achieves its purpose, which is to prevent contact with a family member who has been exposed to violence. In such cases, the imposed protection measure may cease to exist after the offender has served the prison sentence, which is de facto pointless because the family member who is a victim of violence is actually being left without any protection.

The guardianship authority is obliged to keep records and documentation on persons who have been subject to family violence, as well as on persons who have been imposed some protection measure (Article 289 par. 2 of the FA).

\section{Domestic Violence as a Criminal Offence}

The legislators across Europe reacted to the escalating family violence by stipulating adequate criminal law provision. ${ }^{14}$ In Serbia, the criminal offence of domestic violence is regulated in Article 194 of the CC. It is believed that the criminalization of domestic violence, along with the crime of murder of a family member, will help in combating this kind of violence (Đorđević, 2007: 122). Due to the volume of this work, we cannot provide a detailed analysis of this crime but we will analyze its main features, with specific reference to recent case law in this field.

\footnotetext{
because their very existence and operation precludes the repetition of such illicit behavior and protects them from suffering legal consequences". It can be concluded from this well-founded opinion that the court refers to the corresponding quasi-criminal sanctions, regardless of the requirements of civil law provisions.

14 Yet, the crime of domestic violence does not exist in all legislations. For example, English law does not recognize this felony (Burton, 2008: 59, 67). The situation is similar in Germany (V. Milošević, 2009: 29).
} 
The criminal offence of domestic violence has its basic form, three more severe (aggravated) forms, and a special form. The act of commission of the basic form of domestic violence entails endangering the tranquility, physical integrity or mental health of a family member by using violence, threat of attack against life or limb, insolent or ruthless behavior; the prescribed punishment for such offenses is a term of imprisonment ranging from three months to three years (Article 194 par.1 CC). For example, this form of offence exists in case where the defendant enters the victim's room (his daughter in the particular case), starts tearing her clothes, tries to hit her with closed fists and threatens to kill her after she has managed to escape from the room ${ }^{15}$. Theoretically speaking, it is questionable what constitutes the offence in such an activity. The action is consequently defined as endangering the tranquility, physical integrity or mental condition of a family member, while the use of violence, threats, insolent or ruthless behavior are only modes of execution of this crime (see Marković, 2003: 54Lazarević, 2006: 550; Dimovski, 2013: 140). Bearing in mind that this provision uses the permanent verb "endangers", in terms of Article 112 par. 30 of the CC, criminal offense would exist if any of previously mentioned actions was taken only once. However, other authors see the action in the application of violence, threats, insolent or reckless behavior, while endangering the protected values is considered only as a consequence of a criminal offense. In this view, depending on which action is taken, the offence could exist with only one action being present (violence, threat) but also with repeated treatment by the offender or outrageously reckless behavior. The starting point is the fact that the term "threatens" stands as a consequence of the action that can last for a longer or shorter period of time, i.e. it signifies an ongoing condition in which a family member lives. However, bearing in mind that the use of violence and qualified threats may lead to similar consequences of jeopardizing the protected values, it is enough that the action of the offense is taken at least once. In case of insolent or reckless behavior, due to the nature of these acts, what is required is their reoccurrence that could lead to the occurrence of the required impact (see Stojanović, 2006: 474; Škulić, 2014: 39). This issue was considered in the Serbian courts' jurisprudence (see Milenković, 2015: 238-240).

We generally consider that such treatment is correct, i.e. that this criminal offense may be committed as a one-time act. However, we are obliged to provide a clarification which (to some extent) may be perceived as a compromise. Namely, the aforementioned theoretical and practical considerations both hold that the criminal offense can be carried out on a one-time basis when it comes to the use of violence and qualified threats. However, for one-time insolent or

15 Judgment of the Basic (Municipal) Court in Kragujevac no. 3K - 665/13 (01.11.2013), unpublished. 
ruthless behavior to be considered a criminal act, the level of insolence and ruthlessness have to be of such intensity that they can cause the prescribed consequence of the action (Ćorović, 2012: 217). It seems that neither theory nor practice has given much attention to this circumstance, which we consider to be indisputable considering that this is a substantive criminal offense. As previously stated, such an interpretation could make a difference between civil law protection and domestic violence, given the fact that insolent and reckless behavior that is not accompanied with the requisite intensity (which would give rise to the the consequences of this crime) might just be relevant from the point of the FA. Thus, we may summarize: every insolent and ruthless behavior does not necessarily constitute a criminal offense of domestic violence, but it may be the legal ground for family law protection. However, we believe that it would not be wrong if the word "endangers" in the relevant provisions of Article 194 par. 1 of the CC were replaced with the word "jeopardize", which would definitively eliminate the underlying dilemma.

What is meant by "violence" in terms of criminalization of domestic violence? There are authors who believe that the term is clear (Dimovski, 2013: 140). On the other hand, some theorists consider that violence within the meaning of Article 194 of the CC includes physical violence, psychological violence, emotional violence, and partly economic violence, which can be qualified (in a broader context) as psychological violence (see Konstantinović Vilić, 2013: 80-82). Such a view has its basis in provisions of Article 3 (par.1 point b) of the Council of Europe Convention on preventing and combating violence against women and domestic violence (the Istanbul Convention), as well as the relevant documents of the Government of the Republic of Serbia and relevant ministries. ${ }^{16}$ Despite the fact that the present Convention mentions sexual violence, the criminalization of domestic violence in Article 194 CC does not apply to this situation, but it is covered by certain offenses from the group of offenses against sexual freedom (rape, sexual intercourse with a helpless person and prohibited sexual acts). However, bearing in mind that the provision in Article 194 par. $1 \mathrm{CC}$ deals with quite broad terms in determining the manner of committing the criminal act of domestic violence (such as the notion of insolent and ruthless behavior, which may include different versions of mental/psychological, emotional and economic violence), we believe that the notion of violence in terms of the manner of execution of the criminal offense should be understood restrictively,

16 For example, Opšti protokol o postupanju i saradnji ustanova, organa i organizacija u situacijama nasilja nad ženama u porodici i u partnerskim odnosima (the General Protocol on proceedings and cooperation of institutions, authorities and organizations in cases involving violence against women in marital and extramarital relations) was adopted by the Government of the Republic of Serbia on 24th November 2011. The ministries of internal affairs, labor and health have special protocols in this area. 
as explained by Prof. Stojanović: "Violence as a criminal law concept and as an act of commission of criminal offences whose legal description includes the element of violence should be determined in the following manner: It is the use of physical force that represents an attack on one's physical integrity. So, it has to be an (active) action, not an omission. Then, the practice of violence involves the use of force (not a threat), which must be directed at a person's body, and it needs to entail a significant, rougher use of physical force. The term does not include the objective that one wants to achieve by using violence. Violence as an act of commission implies only the use of such physical force that constitutes an attack on one's physical integrity" (Stojanović, 2014: 4). In practice, the use of violence is usually manifested as punching, slapping, pulling, pushing and other similar actions. If violence causes minor bodily injuries, there will not be a concurrence with the offense of causing minor bodily injury, but a joinder of offences on the basis of consumption. This position is held in the jurisprudence as well (see Ćorović, 2012: 253-254)

The threat must be qualified, i.e. manifested as a threat of attack against the life or limb. Otherwise, the very act of threat needs to be understood in a way it is commonly understood in criminal law. Threat is the expression of intention to inflict evil to a person who is being threatened, while the realization of the threatened evil depends on the will of the person who threatens. The evil has yet to occur, i.e. it is about some kind of future evil (Stojanović, 2013: 6). The threat of some other evil is not relevant in the context of this method of execution, but in each case it should be determined whether it can be categorized under insolent or ruthless behavior. If the criminal act of domestic violence is committed by qualified threats, it constitutes the criminal offense of endangering safety.

According to Prof. Lazarević, insolent behavior is the type of behavior that "violates the basic principles of common cultural behavior, which is manifested in ignoring others, insulting, propensity to physical confrontation, and even some forms of threats of attacks on physical integrity". According to the same author, ruthless behavior is close to rude behavior but with stronger intensity, which demonstrates utter disrespect of a family member (Lazarević, 2006: 550).

Domestic violence is one of the criminal acts of endangerment, with the consequence of creating a concrete danger to the tranquility, physical integrity or mental condition of a family member. This consequence, as well as the causal link between it and the action or the specific manner of commission of the offense, must be determined on the merits of each case. It is debatable whether the consequence of endangerment should be understood in a purely objective or in the objective and subjective sense, i.e. whether the passive subject in a particular case has to feel threatened. The prevailing opinion is that subjective experi- 
ence is not necessary; instead, endangerment should be assessed objectively, considering the manner in which the action has been taken in a given situation (Stojanović, 2006: 573). In principle, such a view should be accepted, provided that in some cases "when the court considers it necessary, endangerment can be determined subjectively, based on the threat assessment of the passive subject, which actually depends on his personal experience of a particular situation" (Škulić, 2014: 41). Moreover, this would be necessary in case of single insolent and ruthless behavior in order to determine whether the required consequence occurred. In this context, appropriate psychological and psychiatric expertise would be necessary. If the action was taken in one of the envisaged ways but the consequence did not occur, this would constitute an attempt, which is not punishable.

The term physical integrity should be understood in the bio-psychological sense, as it is understood in offenses against life and limb. Physical integrity includes the anatomical uniqueness, i.e. physical and mental health (see Lazarević, 2006: 379). Tranquility is the feeling of physical and psychological security, while mental condition includes peace of mind, the absence of fear, excitement, and similar circumstances (Lazarević, 2006: 550). Notably, the FA uses the term "mental health" and not a "state of mind". In accordance with the foregoing, mental health falls within the concept of bodily integrity and it does not have identical content as the concept of mental condition.

Active and passive subjects must have the status of a family member in terms of the aforesaid CC provisions. In judicial practice, it is considered that there is only one criminal offence if the physical integrity, tranquility or mental state of several family members is endangered on the particular occasion (see Ćorović, 2012: 251-252). We believe that such practice is contra legem for at least two reasons: first, the legislator uses the singular form, or more precisely "a family member "; second, this offence is aimed against the personal values of an individual, and the rule is that when it comes to personal goods there are as many crimes as persons whose goods are violated or threatened.

A more severe (aggravated) form of domestic violence occurs in case where the the offender, while committing the basic form of the offence, uses weapons, dangerous tools or other means suitable to inflict serious bodily injury or seriously impair another's health. This form of the offence is punishable by a term of imprisonment ranging from six months to five years (Article 194 par. 2 CC). This offence exists when the defendant severely hurts and significantly endangers one's life and health, for example, by hitting the victims on the head with a closed fist several times and with an open hand in the face, wrapping the phone cable around her neck, and using it to cause serious bodily injuries. ${ }^{17}$

17 Judgment of the Basic (Municipal) Court in Kragujevac no. 3K - 1197/13 (15.10.2013), unpublished. 
If the previously described acts have resulted in grievous bodily injury, harm or serious health impairment, or if the act is committed against a minor, the offender shall be punished with imprisonment of two to ten years (Article 194 par. 3 CC). Here, we have three alternatively stipulated consequences, which are manifested in the occurrence of serious bodily injury, severe impairment of health, and commission of the offense against a minor. For example, this offence was committed in case when the defendant threatened the tranquility, physical integrity and mental state of his underage daughter, hit her on the head several times, clutched her neck and threatened her, whereby she sustained minor bodily injuries. ${ }^{18}$

The most severe form of domestic violence exists if the commission of the three previously described forms of the offences results in death of a family member. It is punishable by imprisonment ranging from three to fifteen years (Article 194 par.4 CC).

Finally, the violation of imposed protective measures against domestic violence is envisaged as a special form of the offence, which is punishable by imprisonment of three months to three years, and/or a fine (Article 194 par. 5 CC). The legislator provides that protective measures are imposed by the court in accordance with the law, but it does not mention which law in particular. This attitude is extremely questionable because certain measures result from the family law rules (Đorđević, 2007: 132) and it is inappropriate that their violation is punished in this way (Škulić, 2009: 18). We should draw attention to the fact that the cumulative convictions of imprisonment and a fine are possible. In addition, the protective measures prescribed by the FA are not properly formulated, which causes a problem in their application (Škulić, 2012: 122).

As for the definition of the term 'family member' in context of this criminal offense, the practice has shown variation. This is particularly evident in its special form. Thus, the Basic (Municipal) Court in Kragujevac recently handed down a judgment holding that the defendant could commit this offense against his sister who does not live with him in the same household because: a) this form of offence can exist independently, and 2) this offence is completed by the breach of any protective measure that the court has imposed (which in this case entailed a ban of approaching the victim as well as the prohibition of any insolent, malicious or reckless behavior that endangers her physical integrity, mental health and peace). Therefore, even though the defendant does not live with his sister in the same household, the fact is that they constitute a family in terms of family law. However, the Higher Court in Kragujevac has taken a diffe-

18 Judgment of the Basic (Municipal) Court in Kragujevac no. 3K - 231/13 (09.04.2013), unpublished. 
rent and (in our view) more appropriate stance, arguing that the very name of the offense refers to the fact that the concept of family should be interpreted in the criminal law sense. In criminal proceedings, the status of its participants cannot be determined in accordance with the FA because this would lead to an overly broad interpretation of the term. ${ }^{19}$

The crime of domestic violence is not related to sexual violence. Such behavior, even when committed against a family member, has been incriminated in the group of criminal offenses against sexual freedom. Typical offences of this kind, such as: rape (Article $178 \mathrm{CC}$ ), sexual intercourse with a helpless person (Article $179 \mathrm{CC}$ ), and prohibited sexual acts (Article $182 \mathrm{CC}$ ), include a sexual intercourse or an equal act, or other sexual acts by use of coercion or taking advantage of any situation involving a helpless or a vulnerable person. Article 36 of the Istanbul Convention stipulates that State Parties are to criminalize: a) vaginal, anal or oral penetration of a sexual nature of the body of another person without her/ his consent, using any bodily part or object; b) other sexual acts with a person without her/his consent; c) causing another person to engage in non-consensual acts of a sexual nature with a third person. According to the same article, the consent must be voluntary, and as a result of the person's free will assessed in the context of the surrounding circumstances, while it is provided that the State Parties are obliged to take the necessary legislative or other measures to ensure that the foregoing provisions also "apply to acts committed against former or current spouses or partners as recognized by internal law". As stated above, it is to be expected that the announced amendments to the CC in the area of criminal offenses against sexual freedom will take into account the ideas of the Istanbul Convention, which will expand the criminal zone in the sphere of sexual violence and in relation to family members. Here, we should mention marital rape. As a phenomenon, this kind of rape has been known for centuries, but it is not accompanied by successful criminal prosecution and proceedings for the commission of this act. For many years, especially on the American continent, the courts have denied the possibility of marital rape, leaving the husbands a wide door to act in marriage as they wished. Only in recent years, mostly due to women's activist movements, the views on this type of violence against women have changed (see Hasday, 2000: 1373-1505).

The 2012 amendments to the Serbian CC did not accept proposals of the courts regarding changes in the criminalization of this offense. Among them are the proposals that are primarily related to greater protection of the injured party, especially if the victim is a minor (for example, if the basic or first severe form of the offence has been committed against a minor, the offender shall be punished

19 Judgment of the Basic (Municipal) Court in Kragujevac no. Kž1-82/14 (07.04.2014), unpublished. 
with imprisonment from one to eight years), as well as a proposal that the basic form of the offense is prosecuted on the motion (Žarković, Šurlan, Kiurski, Matić \& Joksimović, 2012: 163-164).

Along with the sentence of imprisonment which is regularly imposed for this criminal offense, the examined judgments show that courts often award a compulsory measure of alcohol addiction treatment, usually in cases involving multiple returnees in the execution of the same criminal offense.

The examples from the American judicial practice show that there is a misconception that violence against women is reflected mainly in less serious bodily injuries. On the contrary, many cases have resulted in death. For example, according to the FBI report, it was established that $32 \%$ of the 3,419 women who were deprived of their lives in the United States in 1998, were killed by their partners, either a current or former spouse, or a former or a current boyfriend (Roberts, 2007: 7-8). According to the opinion of the English Commission for establishing guidelines for punishment, it is clear that violence against women is a very serious offense due to multiple aggravating factors, such as: the abuse of trust, vulnerability, exposure of children, etc. (Burton, 2008: 63-64). In addition, we must keep in mind the fact that nothing is so painful as when the wounds are inflicted by a family member or someone close to your heart (Škulić, 2014: 119-120).

\subsection{Restraining order prohibiting access and communication with the victim}

This security measure was introduced in our criminal law in 2009. It can be said that the ratio legis for its introduction is the suppression of the criminal acts of domestic violence, although it is not strictly related to this criminal offence. In terms of its content, it resembles the mentioned forms of civil law protection against domestic violence under Article 198 par. 2 FA. Given that this criminal sanction seeks to prohibit the perpetrator from approaching and accessing the injured party in his/her place of work and residence, its content essentially implies limiting the perpetrator's freedom of movement.

According to Article 89a par. $1 \mathrm{CC}$, this security measure may prohibit the offender from: a) approaching the injured party at a specified distance; b) accessing the area surrounding the injured party's residence or place of work; c) further harassment of the injured party; d) further communication with the injured party. The court may impose any of these bans if it is reasonably believed that any further action (of approaching, accessing, harassment and communications) would be dangerous for the victim. The term "injured party" should be understood in the sense of Article 2 par. 1 point 11 of the Serbian Criminal Procedure 
Code (CPC) ${ }^{20}$, which implies the "person whose personal or property right has been violated or jeopardized". In addition, when it comes to domestic violence, the victim must be a family member in terms of the relevant CC provisions.

This security measure is imposed along with a fine, community service, suspension of driving license, a suspended sentence and judicial admonition (Article 80 par. $6 \mathrm{CC}$ ). The court determines the duration of these measures which may not be less than six months nor more than three years from the date of the final decision, provided that the time spent in prison or medical institution where the security measure was enforced is not included in the duration of this measure (Article 89a par. $2 \mathrm{CC}$ ). The latter hardly makes any sense, given that the prohibition of approaching and communication with the injured party may not be imposed if the offender has been sentenced to prison, nor against a mentally incapacitated person along with the security measure of compulsory psychiatric treatment and confinement in a medical institution in terms of Article 80 par. 2 CC. This security measure may be revoked before the expiry of the period for which it is determined if the legal grounds for which it was imposed have ceased to exist (Article 89a par. $3 \mathrm{CC}$ ).

However, the execution of this security measure is not adequately regulated. The criminal offence concerning the violation of the prohibition established by the security measure envisaged in Article 340a of the Serbian Criminal Code entered into force on $1^{\text {st }}$ June 2017. Under that provision, we can qualify the situation in which the convicted person (who has been imposed the security measure from Article 89a CC) violates any of the imposed prohibitions. However, the Serbian legislation on the execution of criminal sanctions still does not recognize the security measure prohibiting access to and communication with the victim. Thus, the Act on the Execution of Criminal Sanctions ${ }^{21}$ is not mentioned at all in the relevant Section of the Serbian Criminal Code that is dedicated to the execution of criminal sanctions (Chapter VI), whereas Article 19 of the Act on the Execution of Non-custodial Sanctions and Measures ${ }^{22}$ speaks of "control over the execution of measures concerning the prohibition of approaching, meeting or communicating with some person, or other measures determined by a tribunal". The latter provision, however, relates to the case of procedural ban of approaching, meeting or communicating with a particular person and visiting certain places, as envisaged in Articles 197 and 198 of the CPC (see Ćorović,

20 The Criminal Procedure Code of the Republic of Serbia (hereinafter: CPC), Official Gazette of Serbia no. 72/ 2011, 101/2011, 121/2012, 32/ 2013, 45/2013 and 55/2014.

21 Act on the Execution of Criminal Sanctions, Official Gazette of Serbia no. 55/2014.

22 Act on the Execution of Non-custodial Sanctions and Measures, Official Gazette of Croatia no. 55/2014. 
2015: 227). Due to the above, the respective security measure is a completely ineffective tool in the fight against crime.

\section{A brief overview of the Act on Prevention of Domestic Violence (PDV Act)}

As specified in Article 1 of the PDV Act, this Act regulates the prevention of domestic violence, the procedures before state authorities related to the prevention of domestic violence, and procedures for providing protection and support to the victims of domestic violence. Therefore, this is the legislative act that establishes appropriate ante delictum measures and procedural rules concerning domestic violence. For the purpose of preventing domestic violence, instituting relevant procedures against criminal offenders and providing relevant protection and support to the victims of domestic violence, the PDV Act envisages a corresponding application of relevant provisions of the Serbian Criminal Code (CC), the Criminal Procedure Code (CPC), the Civil Procedure Code, the Family Act (FA) and the Police Act.

We have to emphasize that the Act on Prevention of Domestic Violence (PDV Act) applies to the following offences: stalking (Article 138a CC); rape (Article 178 CC); sexual intercourse with a helpless person (Article 179 CC); sexual intercourse with a child (Article $180 \mathrm{CC}$ ); sexual intercourse involving the abuse of official position (Article $181 \mathrm{CC}$ ); prohibited sexual acts (Article $182 \mathrm{CC}$ ); sexual harassment (Article 182a CC); pimping and procuring (Article 183 CC); mediation in prostitution (Article $184 \mathrm{CC}$ ); showing, procuring and possession of pornographic material and juvenile pornography (Article $185 \mathrm{CC}$ ); inducing a minor to watch sexual acts (Article 185a CC); neglecting and abusing a minor (Article 193 CC); domestic violence (Article 194 CC); failure to provide maintenance (Article 195); violation of family duty (Article 196 CC); incest (Article 197 CC); 17) human trafficking (Article 388. CC); 18) other offences, if it is a consequence of domestic violence.

Finally, the PDV Act introduces the concept of urgent measures in the Serbian legislation. The urgent measure is determined by a competent police officer and it is applicable within the next 48 hours. Upon the public prosecutor's proposal, this measure can be prolonged by the court for 30 days (Articles 17-24 PDV Act). Under Article 36 of the PDV Act, a violation of the urgent measure constitutes a misdemeanor, which is punishable by a term of imprisonment not exceeding 60 days. 


\section{Domestic violence: survey results}

This survey was conducted in the period September-November 2016 in nine lower (municipal) courts located within the territorial jurisdiction of the four appellate courts in Serbia. We have conducted the survey in the following basic (municipal) courts: Belgrade, Novi Sad, Novi Pazar, Pančevo, Valjevo, Kragujevac, Niš, Zaječar and Šabac. In each of the selected courts, we analyzed at least twenty cases related to the criminal offence of domestic violence. In terms of the research sample, we first wish to emphasize that the cases were selected by the method of random sampling. Second, it should be noted the number of analyzed cases decided in the lower and higher courts is large and representative enough to provide for adequate comparisons and verifiable hypothesis that were set forth in the survey. During the research, we have analyzed 119 felonies related to domestic violence from the judicial practice of these lower courts. Using the standardized questionnaire, we collected data from the courts' case files which were analyzed in detail. The research sample included adult offenders only.

First, we analyzed the defendants' gender. As expected, the highest percentage of the perpetrators of this crime were male (in 116 cases), while women were defendants in only 3 cases. Second, in terms of age, the perpetrators were classified into four categories: under 30 years, 31-45 years, 46-60 years, and over 60 years. In the cross-section, 15 defendants were under the age of 30, 49 defendants were aged 31-45, 46 defendants were aged 46-60, and 9 defendants were over the age of 60 . As expected, the middle-aged defendants prevailed in terms of the commission of this crime. Third, we analyzed the defendants' personal profile from the aspect of their education, where they were classified into five categories: incomplete primary school, primary school, secondary school, higher school, and university education. The initial premise was that the highest percentage of offenders would be persons with incomplete primary school and those who completed primary school and secondary school education. The survey results show that 5 perpetrators had incomplete primary school, 42 perpetrators had completed primary school, 60 perpetrators had completed high school, and 10 perpetrators had completed higher school or university education; in three cases, the case files contained no data on the defendants' education. Thus, the starting premise has proven to be correct.

Considering the employment ratio, the perpetrators were categorized into seven categories: unemployed, student, worker, officer, farmer, private entrepreneur, and other jobs. From the total number of 119 cases, 43 defendants were unemployed and 1 was a student; there were 46 workers, 3 officers, 5 farmers, 9 private entrepreneurs, and 10 people had other job; in two cases, the case file did not contain data on the defendants' employment. Then, we analyzed the 
financial status of the offenders, and grouped the results into six categories: no data, very bad, bad, average, good and very good. In 30 cases, the case files contained no data on the defendants' financial standing; 35 defendants were in a very bad financial situation; 27 people reported having a bad financial standing; 24 people stated that their financial status was average and 3 people said it was good, while none of the defendants reported having a very good financial standing. After that, we analyzed their marital status, where we examined whether defendant was married or not. From the total number, 64 defendants were married and 55 were not married. In terms of the family circumstances, we wanted to determine the number of minor children that perpetrators had. As there were several defendants with adult children, their case files were not taken into consideration. The answers from the remaining case files were classified into three categories: no minor children, one minor child, and two or more minor children. The survey results show that 63 offenders were without minor children, 19 offenders had one minor child and 33 offenders had two or more minor children. Four case files contained on data.

We further analyzed the offenders' previous criminal convictions. The answers were categorized into three groups: no previous conviction, one previous conviction, and two or more previous convictions. From the total number, $67 \mathrm{de}-$ fendants had no previous conviction, 28 had one previous conviction, and 23 had two or more criminal convictions for committing a felony. For one offender, the case file contained no data on this issue. Then, we examined whether domestic violence occurred as a separate crime or in the conjunction with one or more offense. The survey results were classified into three categories: domestic violence as a separate crime, domestic violence in conjunction with another felony, and domestic violence in conjunction with two or more felonies. In a total of 103 cases, domestic violence was committed as a separate crime; in 14 cases, it was committed in conjunction with another felony; in only 2 cases, it was committed in conjunction with two or more felonies. In line with the nature of domestic violence, all 119 cases involved completed criminal offenses, and none of the offences remained at the stage of attempt. Almost all the perpetrators acted intentionally (118 perpetrators); not a single perpetrator acted with the negligence, while only one perpetrator was mentally incompetent. All offenses were committed by a single person who had no accomplices.

Particularly interesting and important from the aspect of efficiency of the criminal procedure is the issue of the length of the criminal proceeding, starting from the moment when the crime was reported to the moment when the judgment was rendered final. Surprisingly, as many as 71 cases were legally terminated in a relatively short period of time: up to one year from the moment the crime was reported. Then, 19 cases were terminated within a period of 2 years, 18 
proceedings were terminated within a period of 2-3 years, 7 proceedings were terminated within a period of 3-5 years, and 4 proceedings lasted over 5 years. The perpetrators were ordered custody in 31 cases; in 88 cases, the court did not order custody to the perpetrator, which is surprising given the fact that Serbian courts order custody very often. Another very important issue is the participation of the defense counsel in criminal proceedings. The survey sample shows that 56 perpetrators did not have a defense counsel, 28 offenders had an ex officio defense counsel, while 35 offenders had a defense counsel of their own choice. Only 6 defendants reached a plea bargaining agreement with the public prosecutor. Finally, 108 offenders were found guilty, while only 11 defendants were found to be innocent.

When it comes to criminal sanctions for these felonies, the courts imposed 42 prison sentences, 2 fines, 62 suspended sentences, 3 community service sentences and 27 security measures ( 26 of which were imposed together with a criminal sanction and one independently). We have categorized the awarded prison sentences into several groups: up to 6 months, 6-12 months, 1-3 years, 3-5 years, 5-10 years, over 10 years, and house imprisonment. The prison sentence was mitigated in only 9 cases, and there was only one acquittal from sentence on a legal basis. The courts imposed 13 prison sentences up to 6 months, 13 prison sentences of 6-12 months, 9 prison sentences of 1-3 years, and 7 sentences of house imprisonment.

The situation is quite similar in terms of the mitigating and aggravating circumstances which influenced the court's decision to impose a higher or a lower sentence. Mitigating circumstances were found in 52 cases, where the courts established the following mitigating circumstances: the degree of culpability (in 6 cases), the degree of endangering or damaging the protected goods/values (in 1 case), the specific circumstances under which the offense was committed (in 3 cases), the previous life of the offender (in 26 cases), the offender's personal and family situation (in 38 cases), the defendant's behavior after the committed offense (in 14 cases), and the defendant's attitude towards the victim (in 6 cases). Aggravating circumstances were found in 89 cases, where the courts established the following aggravating circumstances: the degree of culpability (in 9 cases), the degree of endangering or damaging the protected goods/values (in 12 case), the motives for the offense (in 1 case), the circumstances under which the offense was committed (in 3 cases), the previous life of the offender (in 19 cases), the offender's attitude towards the victim (in 3 cases), and recidivism (in 15 cases). The only circumstance that has an obligatory aggravating character is hate. In our survey sample, the courts found this aggravating circumstance in only one case. 


\section{Conclusion}

Although it has been known since ancient times, domestic violence has been brought to public attention only in the last two decades. Primarily under the influence of the feminist movement, legislators across Europe have introduced provisions on domestic violence in their criminal legislations but some more conservative legal systems (e.g. English and German) have kept the traditional forms of criminal justice responses to domestic violence in the context of other crimes. Serbia belongs to the first group of countries because it criminalized domestic violence at the beginning of the $21^{\text {st }}$ century. However, certain provisions of the Serbian Criminal Code (CC) regarding this crime can be put into question. It primarily refers to the provisions on the specific form of domestic violence, where the criminal and family law provisions intertwine. The most problematic issue is the concept of the family unit, which the Family Act (FA) defines in a much broader sense than the Criminal Code. Criminal proceedings for the offense of domestic violence are characterized by a number of specific features, which are closely related to the vulnerable position of the victim as well as to the sensitive circumstances in the family. Public prosecutors in this field apply the principle of opportunity, with particular emphasis on the application of psycho-social treatment measures which treat the problems that have led to the violent behavior in the family community. But, regardless of the (lack of) success in the implementation of certain measures, the protection from domestic violence is an area that calls for continuous improvement of legal solutions. Considering the current state of affairs, this protection will get some new forms through a lex specialis on protection against domestic violence. If trends from the neighboring countries are to be accepted, the new legislation is most likely to be related to the misdemeanor law matter.

However, despite the comprehensiveness of the existing regulations of protection against domestic violence, there is a number of problems to be addressed, including both nomotechnical and conceptual issues, as well as incompatibility of legal provisions envisaged in different laws. In this article, we have pointed out some of these problems and provided some suggestions to overcome them.

In any case, the phenomenon of domestic violence is very complex. Without disputing the need for suppressing domestic violence, we consider that the legal approach may be disputable: should it be done through specific or general incrimination of domestic volence offences; is a lex specialis on this matter necessary or not? Anyway, legal and particularly criminal law protection should not be regarded as "omnipotent", as it is often presented in public. Unfortunately, protection often comes post delictum. Thus, much more needed and more effective are some other (social, educational, etc.) measures which can effectively prevent 
the attack on certain personal goods/values of the family member. Although it may seem as a cliché, the first thing that needs to be changed in this sphere is the outdated, patriarchal or conservative understanding of inter-partner and family relations, in particular the relationship between a man and a woman.

\section{References}

Anetzberger, G. (2008). Abuse and the elderly. In J. Keeling, \& T. Mason (Eds.), Domestic Violence: A multi-profesional approach for healthcare practitioners. Maidenhead: Open University Press.

Babić, I. (2014). Nasilje u porodici i mere zaštite. In D. Kolarić (Ed.), Nasilje u Srbiji-Uzroci, oblici, posledice i društvena reakcija (Vol. 1). Beograd: Kriminalističko policijska akademija- Hanns Seidel.

Bentovim, A. (2009). Growing Up in the Climate of Trauma and Violence: Frameworks for Understanding Family Violence. In A. Bentovim, A. Cox, L. Bingley Miller, \& S. Pezzey (Eds.), Safeguarding Children Living with Trauma and Family Violence: Evidence-Based Assessment, Analysis and Planing Interventions. LondonPhiladelphia: Jessica Kingsley Publishers.

Brewster, M. (2002). Domestic Violence Theories, Research, and Practice Implications. In A. Roberts (Ed.), Handbook of Domestic Violence Intervention Strategies: Polices, Programs and Legal Remedies. Oxford: Oxford University Press.

Burton, M. (2008). Legal Responses to Domestic Violence. Oxon: Rutledge- Cavendish.

Ćorović, E. (2012). Sporni oblici disciplinskog kažnjavanja dece: da li je reč o osnovu isključenja protivpravnosti krivičnog dela ili nasilju nad decom? Crimen, 3. Ćorović, E. (2015). Sistem krivičnih sankcija Republike Srbije. Novi Pazar- Niš: Sven.

Dimovski, D. (2013). Krivičnopravna zaštita žena. In S. Konstantinović Vilić (Ed.), Pravna klinika za zaštitu prava žena- norme i praksa. Beograd- Niš: Autonomni ženski centar Beograd- Ženski istraživački centar za edukaciju i komunikaciju.

Douglas, E. \& Hines, D. (2011). The Helpseeking Experiences of Men Who Sustain Intimate Partner Violence: An Overlooked Population and Implications for Practice. Journal of Family Violence, 473-485.

Đorđević, Đ. (2007). Krivična dela nasilja u porodici. Revija za kriminologiju i krivično pravo, 45. 
Hamel, J. (2007). Domestic Violence: A Gender-Inclusive Conception. In J. Hamel \& T. Nicholls (Eds.), Family Interventions in Domestic Violence. New York: Springer Publishing Company.

Hanak, N., Tenjović, L., Išpanović-Radojković, V., Vlajković, A. \& Beara, M. (2013). Epidemološko istraživanje nasilja nad decom u porodici u Srbiji. Temida, 76.

Hasday, J. (2000). Contest and Consent: A Legal History of Marital Rape. California Law Review, 88.

Ignjatović, Đ. (2002). Kriminološki aspekt delikata nasilja. In D. Radovanović (Ed.), Delikti nasilja: krivičnopravni i kriminološki aspekt. Beograd: Institut za kriminološka i sociološka istraživanja.

Ignjatović, T., Pavlović Babić, D. \& Lukić, M. (2015). Delotvornost sistemskih mehanizama za sprečavanje nasilja prema ženama i nasilja u porodici. Beograd: Autonomni ženski centar.

Jovanović, S. (2012). Nasilje u porodici u Srbiji: učinioci, žrtve i društvena reakcija. Revija za kriminologiju i krivično pravo, 50.

Konstantinović Vilić, S. (2013). Nasilje u porodici- krivičnopravno regulisanje u Srbiji i praksa Evropskog suda za ljudska prava. In S. Konstantinović Vilić (Ed.), Pravna klinika za zaštitu prava žena- norme i praksa. Beograd- Niš: Autonomni ženski centar Beograd- Ženski istraživački centar za edukaciju i komunikaciju.

Kovačević, R. \& Kecman, B. (2007). Ličnost i nasilnički kriminalitet. Revija za kriminologiju i krivično pravo, 45.

Lazarević, L. (2006). Komentar Krivičnog zakonika Republike Srbije. Beograd: Savremena administracija.

Locton, D. \& Ward, R. (1997). Domestic Violence. London-Sidney: Cavendish Publishing Limited.

Lukić, N. (2011). Nasilje među partnerima- analiza karakteristika i uzroka. In Đ. Ignjatović (Ed.), Kaznena praksa u Srbiji. Beograd: Pravni fakultet.

Marković, I. (2003). Primjena odredbe o nasilju u porodici u Republici Srpskoj. Temida, 6.

McGee, C. (2000). Childhood Experiences of Domestic Violence. London- New York: Jessica Kingsley Publishers.

Mildorf, J. (2007). Storying Domestic Violence: Constructions and Stereotypes of Abuse in the Discourse of General Practitioners. Lincoln-London: University of Nebraska Press. 
Milenković, M. (2015). Sudska praksa u borbi protiv kriminaliteta kod krivičnog dela nasilje u porodici iz člana 194. stav 3. u vezi stava 1 . Krivičnog zakonika. In S. Bejatović (Ed.), Suđenje u razumnom roku i drugi krivičnopravni instrumenti adekvatnosti državne reakcije na kriminalitet. Beograd: Intermex- Srpsko udruženje za krivičnopravnu teoriju i praksu.

Milošević, N. (2009). Nasilje u porodici (sa stanovišta krivičnog zakonodavstva i prakse). In M. Škulić (Ed.), Nasilje u porodici. Beograd: Udruženje jevnih tužilaca i zamenika javnih tužilaca Srbije.

Mullender, A. (2006). Rethinking Domestic Violence: The Social Work and Probation Response. London: Routledge.

Mullender, A., Hague, G., Imam, U., Kelly, L., Malos, E. \& Regan, L. (2002). Children's Perspectives on Domestic Violence. London: SAGE Publications.

Panov, S. (2012). Porodično pravo - Priručnik za polaganje pravosudnog ispita. Belgrade: Pravni fakultet Univerziteta u Beogradu- Službeni glasnik.

Parker, J. \& Parker, P. (2003). Domestic Violence: A Medical Dictionary, Bibliography, and Annotated Research Guide to Internet References. San Diego: Helth Care.

Petrušić, N. \& Konstantinović Vilić, S. (2005). Vodič kroz sistem porodičnopravne zaštite od nasilja u porodici. Beograd: Autonomni ženski centar.

Roberts, A. (2002 a). Comparative Analysis of Battered Women in the Community with Battered Women in Prison for Killing their Inmate Partners. In A. Roberts (Ed.), Handbook of Domestic Violence Intervention Strategies: Polices, Programs, and Legal Remedies. New York: Oxford University Press.

Roberts, A. (2002 b). Duration and Severity of Woman Battering. In A. Roberts (Ed.), Handbook of Domestic Violence Intervention Strategies: Policies, Programs, and Legal Remedies. New York: Oxford University Press.

Roberts, A. (2002 c). Myths, Facts and Realities Regarding Battered Women and their Children. In A. Roberts (Ed.), Handbook of Domestic Violence Intervention Strategies: Polices, Programs and Legal Remedies. New York: Oxford University Press.

Roberts, A. (2007). Overview and New Directions for Intervening on Behalf of Battered Women. In A. Roberts (Ed.), Battered Women and Their Families: Intervention Strategies and Treatment Programs. New York: Springer Publishing Company.

Sterne, A. \& Poole, L. (2010). Domestic Violence and Children: A handbook for schools and early year's settings. London-New York: Taylor \& Francis. 
Stojanović, Z. (2006). Komentar Krivičnog zakonika. Beograd: Službeni glasnik. Stojanović, Z. (2013). 0 pojmu pretnje u krivičnom pravu. Nauka, Bezbednost, Policija, 18.

Stojanović, Z. (2014). Krivičnopravni pojam nasilja. In D. Kolarić (Ed.), Nasilje u Srbiji- uzroci, oblici, posledice i društvene reakcije (Vol. I). Beograd: Kriminalističko policijska akademija- Hans Seidel.

Summers, R. W. \& Hoffman, A. M. (2002). United States. In R. W. Summers, \& A. M. Hoffman (Eds.), Domestic Violence: A Global View. Connecticut - London: Greenwood Press.

Škulić, M. (2009). Osnovni elementi normativne konstrukcije krivičnog dela nasilja u porodici- neka sporna pitanja i dileme. In M. Škulić (Ed.), Nasilje u porodici. Beograd: Udruženje javnih tužilaca i zamenika jevnih tužilaca.

Škulić, M. (2012). Nasilje u porodici: nedovoljno kvalitetno zakonsko rešenje, nedosledna praksa, brojni problemi i dileme. Revija za kriminologiju i krivično pravo, 50.

Škulić, M. (2014). Nasilje u porodici: Neki problemi zakonske inkriminacije i sudske prakse. In D. Kolarić (Ed.), Nasilje u Srbiji- uzroci, oblici, posledice i društvene reakcije (Vol. 1). Beograd: Kriminalističko policijska akademija- Hanns Seidel.

Turković, K. \& Maršavelski, A. (2013). Komentar Kaznenog zakona i drugi izvori novog hrvatskog kaznenog zakonodavstva. Zagreb: Narodne novine.

Vlašković, V. (2008). Porodičnopravna zaštita od nasilja u porodici. Kragujevac: Univerzitet u Kragujevcu.

Vlašković, V. (2013). O dve karakteristične usluge iz domena pravne zaštite od porodičnog nasilja u engleskom i austrijskom pravu. In M. Mićović (Ed.), XXI vek- vek usluga i uslužnog prava. Kragujevac: Univerzitet u Kragujevcu.

Žarković, M., Šurlan, T., Kiurski, J., Matić, M. \& Joksimović, S. (2012). Ka boljoj zaštiti žrtava nasilja u porodici: odgovor pravosuđa. Beograd: Udruženje javnih tužilaca i zamenika javnih tužilaca Srbije. 


\section{Др Вељко Турањанин,}

Доцент Правног факултета Универзитета у Крагујевцу

Др Емир Ћоровић,

Доцент Државног универзитета у Новом Пазару

Др Драгана Чворовић,

Доцент Криминалистичко-полицијске академије у Београду

\section{НАСИЉЕ У ПОРОДИЦИ У СРБИЈИ}

\section{Резиме}

Насиље у породици представља једно од најкомплекснијих питања у кривичном праву, а које представља негацију основних људских права и слобода заштићених бројним међународним и унутрашњим правним документима, почев од права на живот и сигурност. Аутори анализирају ову све присутнију форму насиља (психичког, физичког, економског и социјалног), као друштвени феномен са аспекта кривичног и кривичног процесног права. Породично насиље пре свега погађа жене. Аутори су спровели истраживање за време десетогодишњег важења Кривичног законика у Србији, с циљем изучавања кривичног дела насиља у породици, поступка за ово кривично дело и његових извршилаца.

Кључне речи: насиље у породици, узроци насиља, грађанско правна заштита од насиља у породици, кривичноправна заштита од насиља у породици, судска пракса за кривично дело насиље у породици. 